\title{
Discursos sobre a corrupção nas votações do Supremo Tribunal Federal (2015-2017)
}

\author{
Corruption speeches in the votes at the \\ Supreme Federal Court (2015-2017)
}

\section{Daniel Fonseca Fernandes ${ }^{1}$}

Centro Universitário Jorge Amado - Salvador/BA, Brasil

danielfonsecafernandes@outlook.com

http://lattes.cnpq.br/6625659216862961

http://orcid.org/0000-0003-2831-1524

Tainan Bulhöes Santana ${ }^{2}$

Universidade Católica do Salvador-Salvador/BA, Brasil

tainan.santana00@gmail.com

http://lattes.cnpq.br/6904902529045823

Dttp://orcid.org/0000-0002-9581-620X

Resumo: Este artigo analisa os discursos sobre a corrupção nas votações do Supremo Tribunal Federal, entre os anos de 2015 e 2017. A pesquisa empírica realizada tem caráter qualitativo e utiliza técnicas de pesquisa bibliográfica e documental, por meio da coleta e análise de decisões colegiadas do Supremo, referentes ao crime de corrupção passiva. A pesquisa se orienta pelo seguinte problema: quais discursos sobre a corrupção foram mobilizados pelos ministros do Supremo Tribunal Federal nos julgamentos colegiados entre os anos de 2015 e 2017? Para posicionar estes discursos, o trabalho reflete sobre categorias centrais do pensamento social brasileiro, como "patrimonialismo", problematizando seus usos pelos juristas. A atuação do Supremo é

1 Mestre em Direito pela UFBA. Professor de Direito Penal e Processo Penal na UNIJORGE. Membro do Grupo Clandestino de Estudos em Controle, Cidade e Prisões. Membro do NESP/UFBA. Membro do IBADPP. Advogado.

2 Pós-graduando em Ciências Criminais pela UCSAL. Bacharel em Direito pela UFBA. Bacharel em Humanidades pela UFBA. Advogado. 
contextualizada a partir dos fenômenos do Mensalão e da Lava Jato e as pressões por determinados resultados exercidas sobre a Corte. As relações com a imprensa, as pressões das agências judiciais e as disputas internas são destacadas como fatores importantes para compreender as decisões.

Palavras-Chave: corrupção; Supremo Tribunal Federal; Mensalão; Lava Jato.

ABSTRACT: This article analyzes the speeches about corruption in the votes of the Supreme Federal Court, between the years 2015 and 2017. This empirical research has a qualitative character and uses bibliographic and documentary research techniques, through the collection and analysis of Supreme collegiate decisions, referring to the crime of passive corruption. The research is guided by the following problem: which speeches about corruption were mobilized by the ministers of the Supreme Federal Court in the collegiate judgments between the years 2015 and 2017? To position these speeches, the work reflects on central categories of Brazilian social thought, such as "patrimonialism", questioning their uses by jurists. The Supreme Court's performance is contextualized based on the Mensalão and Lava Jato phenomena and the pressure for certain results exerted on the Court. Relations with the press, pressure from judicial agencies and internal disputes are highlighted as important factors in understanding decisions.

Keywords: corruption; Supreme Federal Court; Mensalão; Lava Jato.

SUMÁRIO: Introdução; 1. Corrupção e patrimonialismo: os riscos do anacronismo; 2. Mensalão e Lava Jato: reposicionando o Supremo Tribunal Federal; 3. Os discursos sobre a corrupção no Supremo Tribunal Federal (2015-2017); Considerações Finais; Referências.

\section{INTRODUÇÃO}

Este artigo analisa os discursos sobre a corrupção nas votações do Supremo Tribunal Federal (STF), entre os anos de 2015 e 2017. Com o objetivo de compreender as concepções políticas que norteiam as decisões da Corte, a análise dos julgados foi feita a partir do contexto posterior ao Mensalão (AP 470/MG) e contemporâneo à Operação Lava Jato, 
encarados como marcos importantes que contribuíram para posicionar o STF nos debates públicos.

O Supremo tem vivenciado, nas últimas duas décadas, um processo intenso de ressignificação do seu papel. A expansão de sua atuação e aumento da exposição à sociedade fizeram com que a Suprema Corte passasse a figurar no centro da vida política brasileira.

Este processo se deu por uma série de fatores, destacados por Recondo e Weber ${ }^{3}$, que vão desde uma maior abertura para análise popular (por meio da assessoria de imprensa, transmissão televisionada e pela internet) ao ingresso dos ministros em rede sociais e aumento da frequência de suas entrevistas. Além disso, os autores também destacam algumas modificações normativas, que promoveram a ampliação das modalidades de controle de constitucionalidade e retiraram a necessidade de autorização prévia do Congresso para o exercício da competência penal originária.

As relações entre o Supremo e a sociedade se constroem a partir de conexões complexas. Se por um lado, essa abertura confere maior transparência à atuação do Tribunal, de outro, há uma exposição enquanto atores centrais da cena política, fragilizando, de certo modo, a legitimidade da Corte e expondo suas contradições.

É neste cenário que os discursos de combate à corrupção têm sido determinantes na conformação dos papeis das agências judiciais no Brasil e, em especial, do STF. As disputas discursivas em torno deste tema têm proporcionado uma série de ações, que buscam reconfigurar os limites e o alcance das normas incriminadoras.

Num contexto em que a corrupção é tratada como uma espécie de "mito fundador" da nação - do senso comum ao pensamento social brasileiro -, o combate à corrupção adquiriu, nas últimas décadas, centralidade política, passando a ocupar posição destacada nos órgãos de comunicação social, na plataforma das agências políticas e nas demandas das agências policiais e judiciais.

A primeira seção deste artigo se dedica a problematizar o tratamento da corrupção no pensamento social brasileiro, abordando,

3 RECONDO, Felipe; WEBER, Luiz. Os Onze: o STF, seus bastidores e suas crises. São Paulo: Companhia das Letras, 2019, p. 88-94. 
especialmente, a noção de patrimonialismo e sua utilização em grande parte dos discursos contemporâneos de combate à corrupção.

O momento atual da conjuntura da Suprema Corte e da política brasileira pode ser compreendida como um período pós-Mensalão (AP 470/MG). Esta ação penal, que envolveu réus que ocuparam altas posições ligadas ao governo federal, foi iniciada em julho de 2005, teve seu julgamento iniciado em 2012 e o esgotamento da fase recursal no primeiro semestre de 2014. A investigação, cobertura midiática e julgamento desta ação penal criaram, por uma década, um movimento com efeitos importantes na vida política do país, ao passo em que contribuíram para a reconfiguração do papel do STF no chamado combate à corrupção.

Ao tempo em que o Mensalão chegava a seu desfecho, foi iniciada a Operação Lava Jato. Este fenômeno também passa a ocupar um lugar central para pensar os discursos de combate à corrupção e o papel do Supremo Tribunal Federal. A partir deste momento, é preciso observar com atenção as relações do STF com a Lava Jato e os movimentos anticorrupção, para tentar compreender sua influência nos discursos e posturas dos ministros nas votações. A segunda seção do artigo se dedica a contextualizar e caracterizar estas dinâmicas, identificando suas relações com episódios e decisões importantes do Supremo.

A partir do objetivo mais amplo, de analisar os discursos do Supremo e de seus ministros sobre a corrupção, foi definido como objeto de análise decisões do STF sobre o tema. Como “corrupção” é um termo abrangente, com significados diversos, que remetem a práticas sociais e tipos penais variados, optamos por analisar decisões colegiadas ${ }^{4}$ do STF a respeito do crime de corrupção passiva, do artigo 317 do Código Penal ${ }^{5}$.

4 Apesar de estarmos cientes de que as decisões monocráticas dos ministros têm tido cada vez mais importância e centralidade no dia-a-dia da Corte, optamos por analisar as decisões colegiadas em que são fixados os entendimentos das Turmas e do Pleno, com maiores possibilidades de debate acerca do tema.

5 A corrupção passiva é crime cometido pelo funcionário contra a Administração Pública. O tipo penal apresenta a seguinte estrutura: Art. 317 - Solicitar ou receber, para si ou para outrem, direta ou indiretamente, ainda que fora da função ou antes de assumi-la, mas em razão dela, vantagem indevida, ou aceitar promessa de tal vantagem. 
O recorte da pesquisa de jurisprudência, centrado neste crime em específico, justifica-se pelo tom dos debates sobre a corrupção no país, que assentam julgamentos morais mais rigorosos sobre os agentes públicos. Esta é uma premissa deste trabalho. Além disso, foi sobre o julgamento destes agentes públicos que o Mensalão se apresentou como "divisor de águas” da política nacional e dos papeis institucionais do STF ${ }^{6}$. A terceira seção deste artigo é dedicada à análise destes discursos.

Consideramos que o período nomeado de "pós-Mensalão" se inicia em 2014, com o julgamento dos embargos infringentes que esgotavam as possibilidades de recursos naquele caso. Deste modo, os acórdãos selecionados foram proferidos em julgamentos realizados entre os anos de 2015 e 2017.

Pensando o tema a partir das ciências criminais, buscamos construir uma análise que dialoga com premissas estabelecidas pela criminologia crítica, direcionando o enfoque aos "mecanismos institucionais", que constroem a realidade social do desvio e realizam os processos de criminalização, tendo na ação das agências punitivas um de seus objetos de análise. Neste sentido, não analisaremos causas, efeitos ou meios para reduzir a corrupção, como é recorrente nas pesquisas sobre o tema ${ }^{8}$.

A construção do trabalho orienta-se pela seguinte questão: quais discursos sobre a corrupção foram mobilizados pelos ministros do Supremo Tribunal Federal nos julgamentos colegiados entre os anos de 2015 e 2017 ?

Partimos da premissa de que as oscilações do papel atribuído ao Supremo Tribunal Federal no chamado combate à corrupção, entre o Mensalão e a Lava Jato (ora como canalizador da "voz das ruas", ora como entrave a este combate), tem implicações importantes na construção dos

6 Ainda que figuras de destaque do Partido dos Trabalhadores (PT), como os ex-Ministros José Dirceu e José Genoíno, tenham sido condenadas por corrupção ativa, há uma ideia, mais ou menos difusa, de que se trata de um julgamento sobre agentes políticos que lesaram o patrimônio público.

7 BARATTA, Alessandro. Criminologia crítica e crítica do direito penal. 3. ed. Rio de Janeiro: Revan: Instituto Carioca de Criminologia, 2002, p. 160.

8 MARANI, Sílvio César Zákhia; BRITO, Mozar José de; SOUZA, Gustavo Costa de; BRITO, Valéria da Glória Pereira. Os sentidos da pesquisa sobre corrupção, Revista de Administração Pública, v. 52, n. 4, p. 712-730, jul./ago. 2018, p. 714. 
discursos na jurisprudência da Corte, ampliando o alcance do tipo penal de corrupção passiva e fazendo avançar seu conteúdo político.

\section{Corrupção e patrimonialismo: os RISCOS do ANACRONISMO}

A corrupção é tratada como "mal de origem" do Brasil, uma espécie de marca histórica do processo colonial brasileiro que condiciona as relações sociais no país. As ligações entre burocracia estatal, ineficiência e corrupção são uma constante em boa parte do pensamento social brasileiro. De certa maneira, os autores clássicos deste campo ajudaram a criar uma imagem da corrupção enquanto um elemento constitutivo da formação social do Brasil.

As obras de Sérgio Buarque de Holanda, Gilberto Freyre, Raymundo Faoro são bastante representativas desta tradição. O mandonismo, pensado por Freyre, pode ser entendido como o conjunto de instintos de posse e mando dos particulares, que estaria na base da construção dos abusos e violência da casa-grande. Para este autor, esta categoria serve para designar o "exagero privatismo ou individualismo" dos proprietários das terras no processo de colonização?.

A noção de patrimonialismo pode ser compreendida como a sobreposição dos interesses particulares na gestão da coisa pública. Esta ideia se tornou uma categoria central para descrição da "formação do Brasil”, especialmente a partir do trabalho de Sérgio Buarque de Holanda, no contexto da informalidade própria do homem cordial, avesso às formalidades, às regras impostas pela civilidade e seu potencial coercitivo ${ }^{10}$.

O patrimonialismo também é mobilizado e aprofundado por Raymundo Faoro, que apresenta o Estado patrimonial como empecilho para a "autonomia da empresa", uma vez que restringe as liberdades públicas (econômicas, do livre contrato, da livre concorrência e da livre profissão) ${ }^{11}$.

9 FREYRE, Gilberto. Casa-Grande \& Senzala. In: Obra escolhida. Rio de Janeiro: Editora Nova Aguillar, 1977, p. 270.

10 HOLANDA, Sérgio Buarque de. Raízes do Brasil. 26. ed. São Paulo: Companhia das Letras, 1995, p. 146-147.

11 FAORO, Raymundo. Os donos do poder: formação do patronato político brasileiro. 5. ed. São Paulo: Globo, 2012, p. 35. 
Outras categorias, igualmente problemáticas, compõem o imaginário social e acadêmico em torno da ideia de corrupção. Um bom exemplo é a categoria do "jeitinho brasileiro", concebida por Roberto DaMatta. Supondo que nos Estados Unidos, na França ou na Inglaterra "as regras ou são obedecidas ou não existem”, o autor vai pensar no “jeitinho" enquanto "modo de navegação", que atravessa continuamente as fronteiras da lei, sendo, para ele, um padrão de conduta marcadamente brasileiro ${ }^{12}$.

Estas categorias concebidas por autores importantes do pensamento social brasileiro são centrais na construção das hipóteses históricas da formação colonial brasileira. No entanto, como observa Jessé Souza, a categoria do patrimonialismo, em especial, parte de uma concepção liberal e conservadora da sociedade brasileira, onde o "Estado patrimonial" aparece como causa do atraso nacional ${ }^{13}$.

O Estado é apresentado, nessa explicação, como local por excelência da corrupção, sendo tratado como entidade gerida por uma atitude particularista, dirigida à manutenção de privilégios e interesses privados. A confusão entre público e privado aparece como categoria que vai atravessar gerações de pensadores brasileiros para explicar o "estado atual das coisas". Para Souza, o patrimonialismo vai ser apresentado como "maldição" ou "mal de origem" ${ }^{14}$.

A observação sobre a estrutura colonial brasileira a partir das noções contemporâneas de separação/confusão do público e o privado se apresenta como anacronismo histórico recorrente nos trabalhos sobre corrupção ${ }^{15}$. As referências frequentes e pouco contextualizadas a textos dos séculos XVI e XVII, como a Carta de Pero Vaz de Caminha, o livro de autoria controversa "A arte de furtar" e os escritos do Padre Antônio Vieira, são um retrato desta prática em trabalhos acadêmicos.

12 DAMATTA, Roberto. O que faz o brasil, Brasil? Rio de Janeiro: Rocco, 1984, p. 97.

13 SOUZA, Jessé. O patrimonialismo é o problema brasileiro? Revista Simetria, São Paulo, v. 1, n. 3, p. 29-40, 2017, p. 33.

14 Ibidem, p. 34.

15 ROMEIRO, Adriana. A corrupção na Época Moderna - conceitos e desafios metodológicos. Revista Tempo, v. 21, n. 38, p. 216-237, dez. 2015, p. 216. 
A elevação do patrimonialismo à categoria mítica, que atravessa a história brasileira, serve para encobrir elementos centrais de sua formação social: a escravidão e a participação privada na apropriação da riqueza e manutenção das violências de dominação e exploração. O interesse particular vai ser apresentado como interesse "individual privado", esvaziando o potencial de compreensão das classes dominantes nos rumos do país ${ }^{16}$. O mercado, concebido enquanto espaço virtuoso, vai ser apresentado como vítima dos atrasos impostos pelo patrimonialismo.

Mesmo na melhor produção da historiografia crítica, é possível identificar certa apresentação da corrupção e do patrimonialismo enquanto vícios de origem. Neste contexto, é possível identificar na obra de uma historiadora da importância de Lilia Schwarcz as noções de patrimonialismo e corrupção enquanto "inimigos da República"17. A autora não realiza transposições simplistas nem pensa a corrupção como fenômeno exclusivamente brasileiro. Contudo, a forma como sua análise é construída apresenta dois graves problemas: uma linguagem bélica, adotando uma gramática de guerra, a partir da noção de inimigo, e o apelo à categoria da impunidade, para pensar a causa da perpetuação destas práticas e do "excesso de burocracia"18.

Este é o repertório mobilizado por setores das agências punitivas que buscam, nos dias de hoje, de maneira exponencial, o alcance das normas e práticas punitivas, com pouca preocupação com as estruturas democráticas. O discurso do inimigo é chave mestra que destrava os limites possíveis impostos pelo sistema jurídico às práticas punitivas.

É evidente que há base histórica concreta para pensar a ingerência do poder privado na gestão da punição, na distribuição de riquezas e acesso aos espaços de poder. Vários estudos sobre a punição de escravizados, por exemplo, revelam pistas importantes sobre esta realidade histórica ${ }^{19}$. Do mesmo modo, é correto afirmar que o colonialismo, suas práticas de

16 SOUZA, op. cit., p. 39.

17 SCHWARCZ, Lilia Moritz. Sobre o autoritarismo brasileiro. São Paulo: Companhia das Letras, 2019, p. 65.

18 Ibidem, p. 87-101.

19 BATISTA, Nilo. Pena pública e escravismo. In: NEDER, Gizlene (Org.). História \& Direito: jogos de encontros e transdisciplinaridade. Rio de Janeiro: Revan, 2007, p. 27-62; LARA, Silvia Hunold. Campos da violência: escravos e senhores na Capitania do Rio de Janeiro, 1750-1808. Rio de Janeiro: Paz e Terra, 1988. 
espoliação das riquezas, gestão da vida e naturalização das violências, opera também através da corrupção.

No entanto, é equivocado pensar a corrupção descolada da existência das práticas internacionalizadas do capitalismo, que se estabelecem por meio das grandes navegações, da conquista brutal dos territórios e do genocídio e escravização das populações não-europeias. Este modo de produção internacionalizado sempre admitiu, de uma forma ou de outra, as práticas que lhe sejam funcionais, especialmente nas antigas colônias, lucrando com elas, e ocultando suas relações umbilicais com os meios de circulação e apropriação da riqueza.

Diversas produções acadêmicas sobre a corrupção ignoram a historicidade dos sistemas políticos e econômicos, que, em cada época, condiciona as relações sociais, os padrões de desvio e o repertório punitivo. Portanto, pensar as relações de corrupção no Brasil exige pensar os modos de produção, suas formas de distribuição de riqueza e as relações entre Estado e mercado, entre poder público e iniciativa privada. Não é suficiente aplicar uma chave simplificadora que denuncia o uso da coisa pública como se fosse propriedade privada. Assim, é necessário deslocar certa identificação entre Estado e corrupção, que ainda é bastante presente no âmbito acadêmico e nos discursos dos juristas ${ }^{20}$.

Atualmente, toda esta tradição do pensamento social brasileiro tem grande influência nos discursos produzidos por cientistas sociais e juristas que se propõem a apresentar interpretações sobre a corrupção. A noção do Estado centralizador como obstáculo à inciativa privada vai reaparecer, de maneira anacrônica, sob a forma de "neopatrimonialismo"21.

É recorrente no discurso dos juristas a noção de "corrupção sistêmica"22, que, curiosamente, oscila entre o anacronismo das transposições

20 As pesquisas de Sutherland, nos anos 1940, cumpriram uma função essencial de romper com os ciclos simplistas de explicação do crime nos circuitos de pobreza, miséria e subdesenvolvimento, ao expor a prática dos crimes no coração das grandes empresas norte-americanas. Ver: SUTHERLAND, Edwin. Crime de colarinho branco. Rio de Janeiro: Revan, 2015, p. 32.

21 SOUSA, Luís de. Corrupção. Lisboa: Fundação Francisco Manuel dos Santos, 2011, p. 48-49.

22 FARIA, José Eduardo. Corrupção, justiça e moralidade pública. São Paulo: Perspectiva, 2019, p.27. 
históricas apressadas e o ar de novidade deste caráter "sistêmico" ou "endêmico". Juristas conhecidos, como Luiz Flávio Gomes, a partir de um emprego curioso do conceito de patrimonialismo, passaram a mobilizar categorias como "cleptoplutocracia" ${ }^{23}$, apresentada mais com uma função de panfleto político do que de categoria teórica.

Estas compreensões precisam ser problematizadas, tendo em vista suas influências nos discursos que compõem os julgados do Supremo Tribunal Federal. Três aspectos são importantes para esta análise. O primeiro, consiste na curiosa transposição da noção de patrimonialismo. Os membros das agências judiciais que têm protagonizado estes debates nos últimos anos - em especial, do Ministério Público e do Poder Judiciário - apresentam, por vezes, uma crítica à corrupção estatal sob as bases da crítica ao patrimonialismo do pensamento social clássico. Há neste fato um paradoxo interessante: no campo da punição, as altas frações do funcionalismo brasileiro (procuradores, juízes e ministros), sustentam abertamente um discurso anti-estatal, sem que estas bandeiras afetem seus próprios vencimentos ou lhes reduza o espaço de poder no cenário político e institucional ${ }^{24}$.

Estes discursos são mobilizados sem constrangimento, ignorando, por exemplo, a crítica dos autores clássicos à constituição do Estado estamental e o papel dos bacharéis e demais sujeitos das agências judiciais. Como num passe de mágica, os portadores destes discursos se colocam fora do problema, como agentes externos capazes de provocar a mudança necessária. As relações entre patrimonialismo e bacharelismo ${ }^{25}$ são colocadas à sombra.

O segundo aspecto consiste no fato de que muitos destes atores, com papel central na Lava Jato, chamados por Chaloub e Lima de juristas

23 GOMES, Luiz Flávio. O jogo sujo da corrupção. Bauru: Astral Cultural, 2017, p. 233.

24 Algumas pistas sobre as posições corporativas e interesses de frações da classe média podem ser observadas em: BOITO JR., Armando. Lava Jato, classe média e burocracia de Estado. In:___. Reforma e crise política no Brasil: os conflitos de classe nos governos do PT. Campinas: Editora da Unicamp, 2018, p. 253-264.

25 ADORNO, Sérgio. Os aprendizes do poder: o bacharelismo liberal na política brasileira. 2. ed. São Paulo: Edusp, 2019, p. 81-87. 
políticos, apresentam uma evidente "percepção rebaixada e corrupta do Estado", responsável pelo atraso, ao passo em que o mercado é representado como lugar do moderno, da inovação e progresso econômico ${ }^{26}$.

O terceiro aspecto consiste na necessidade de manter certa desconfiança crítica em relação aos discursos de produção de verdade oficial. Ao longo da história, há vários registros de acusações de corrupção para deslegitimar adversários políticos ${ }^{27}$, sendo um expediente comum a governos autoritários, que, não raro, têm nos "corruptos" a imagem de um inimigo importante a ser combatido, por meio de uma confusão intencional entre o jurídico e o moral ${ }^{28}$. No campo da política, disputa-se uma determinada superioridade ética e pureza moral de princípios, sendo fundamental evitar os estigmas da corrupção.

Além da influência destas categorias, que remetem à composição social do Brasil e são determinantes na expressão dos juristas, é preciso também compreender os dois fenômenos que marcam de forma decisiva os debates sobre a corrupção no Brasil e suas influências no Supremo Tribunal Federal.

\section{Mensalão e Lava Jato: reposicionando o Supremo Tribunal Federal}

A partir do julgamento do Mensalão, o STF passou por um processo mais intenso de abertura às influências da opinião pública ou à "voz das ruas"29. As pressões da imprensa, dos movimentos sociais mais

26 CHALOUB, Jorge; LIMA, Pedro Luiz. Os juristas políticos e suas convicções: para uma anatomia do golpe de 2016 no Brasil. Revista de Ciências Sociais, Fortaleza, v. 49, n. 1, p. 202-252, mar./jun. 2018, p. 216.

27 MOURA, Denise. Jogo de acusações: denúncias de mau governo e competição de interesses na América portuguesa. In: BIASON, Rita; LIVIANUI, Roberto (Org.). A corrupção na história do Brasil. São Paulo: Editora Mackenzie, 2019, p. 54.

28 KIRCHHEIMER, Otto. Criminal Law in National Socialist Germany. In: SCHEUERMAN. William. (Ed.) The Rule of Law Under Siege: selected essays of Franz L. Neumann and Otto Kirchheimer. Los Angeles: University of California Press, 1996, p. 174-175.

29 RECONDO; WEBER, op. cit., p. 72. 
ou menos organizados e, posteriormente, das redes sociais, passaram a exercer um efeito conformador mais visível nas decisões do Supremo.

No campo da política criminal, é possível observar um curioso movimento de bumerangue nos discursos sobre a corrupção. As agências judiciais ${ }^{30}$, em grande medida, fomentam políticas de ampliação do alcance das normas incriminadoras, insuflando movimentos sociais e alimentando a mídia de informações selecionadas, com objetivo de alçar o combate à corrupção à condição de pauta prioritária no país.

Estes grupos devolvem às agências judiciais uma demanda para fortalecer o combate à corrupção a qualquer custo, seja através de uma cobertura midiática massiva e interessada, seja através de propostas legislativas ou reivindicações coletivas nas redes sociais ou nas ruas. Deste modo, o movimento que ganha corpo entre as agências judiciais - dentre as quais se destaca o Ministério Público Federal (MPF) - retorna como pressão por resultados ${ }^{31}$ nos processos contra a corrupção, produzindo um especial efeito conformador nos Tribunais.

É este retorno que pretendemos analisar no presente artigo, por meio da análise dos discursos dos ministros do Supremo Tribunal Federal, nos julgamentos colegiados sobre o crime de corrupção passiva.

A premissa adotada - de que os conceitos de patrimonialismo e corrupção, desenvolvidos no pensamento social brasileiro, são centrais para a conformação das manifestações contemporâneas dos juristas - se soma à necessidade de situar a Corte em relação aos fenômenos recentes que provocaram uma importante reconfiguração de seu papel. Parte daí a escolha de analisar a jurisprudência do STF sobre o crime de corrupção passiva, uma vez que a noção mais difusa de corrupção está relacionada a uma ideia de máquina estatal "pesada”, burocrática, que representa um entrave ao mercado e seus atores.

30 ZAFFARONI, Eugenio Raúl; BATISTA, Nilo; ALAGIA, Alejandro; SLOKAR, Alejandro. Direito Penal Brasileiro: primeiro volume. 4. ed. Rio de Janeiro: Revan, 2011, p. 60-61.

31 Os resultados pretendidos nos movimentos anti-corrupção são sempre decisões condenatórias. Através desta maneira de pensar, estes movimentos contribuem para deslegitimação do processo penal, uma vez que a absolvição (resultado tão legítimo quanto a condenação), é equiparada à complacência com o crime, sendo identificada à categoria problemática da impunidade. 
Tomando o julgamento do Mensalão como ponto de partida, é essencial compreender a atuação da mídia para observar o entrelaçamento das pressões sobre a Corte. Algumas leituras, como a apresentada por Joaquim Falcão ${ }^{32}$, atribuem papel central aos órgãos de imprensa, desde o recebimento da denúncia ao julgamento do processo. A apresentação inicial dos fatos pela imprensa e o "batismo" do esquema de corrupção a partir de uma entrevista do deputado delator são momentos destacados por Luis Felipe Miguel e Aline Coutinho ${ }^{33}$ para compreensão destas influências.

Se nos primeiros meses do "escândalo" foi possível perceber um comportamento "incendiário" por parte dos grandes meios de comunicação, nos meses seguintes havia certa tentativa de recomposição, quando as implicações passaram a atingir o Ministério da Fazenda, comandado então por Antônio Palocci. Este movimento de grandes jornais, nos primeiros momentos do Mensalão, entre 2005 e 2006, apesar de ter tido um caráter de denúncia "personalista" da corrupção, focado em desgastar e responsabilizar o Partido dos Trabalhadores (PT) e o ex-Presidente Lula, não se encaminhou para propostas mais radicais que propusessem uma reformulação econômica e política ou de ruptura do modelo de democracia representativa ${ }^{34}$.

Especialmente na fase de julgamento do Mensalão, iniciada em 2012, a cobertura pela mídia foi retomada com maior intensidade, com transmissões frequentes, resumos dos acontecimentos do dia e altos níveis de audiência. A narrativa construída por meio da atuação de veículos da grande imprensa brasileira estabeleceu papeis dos sujeitos envolvidos no julgamento: ao Procurador Geral da República (PGR) eram reservadas expressões elogiosas, que ressaltavam seu heroísmo e coragem, destacando o caráter "técnico" de sua atuação; de outro lado, réus como José

32 FALCÃO, Joaquim. Direito, mídia e opinião pública. In.: FALCÃO, Joaquim (Org.). Mensalão: diário de um julgamento. Supremo, mídia e opinião pública. 2. ed. rev., atual. e ampl. Rio de Janeiro: Forense; São Paulo: Método, 2015, p. XXIII.

33 MIGUEL, Luis Felipe; COUTINHO, Aline. A crise e suas fronteiras: oito meses de "mensalão" nos editoriais dos jornais. Opinião pública, Campinas, v. 13, n. 1. jun. 2007, p. 98.

34 Ibidem, p. 120-121. 
Dirceu, figura central do Partido dos Trabalhadores, eram retratados de forma depreciativa ${ }^{35}$.

A proporção do caso e a forma de exploração pela imprensa tiveram efeitos importantes no julgamento do Mensalão e em seus desdobramentos, sendo peça central para reposicionar o Supremo nos debates públicos, a ponto de alguns ministros responderem diretamente a alegações da imprensa durante a leitura de seus votos ${ }^{36}$.

Dentro da Corte, os papeis atribuídos aos Ministros Joaquim Barbosa (relator) e Ricardo Lewandowski (revisor) também são reveladores destas pressões e da maneira de construção deste escândalo político nos órgãos de comunicação. A construção de uma imagem heroica em torno da atuação de Barbosa contrastava com a imagem sempre suspeita de Lewandowski.

O ponto central que interessa a esta análise é que a extensão da cobertura midiática e construção das narrativas em torno dos atores envolvidos reforçou a pressão sobre a Corte para condenação dos acusados. Neste movimento, o que se verifica é que a própria legitimidade do Supremo Tribunal Federal é colocada em questão, como se dependesse de um resultado já sabido e desejado pela grande imprensa e parte da opinião pública, sendo possível afirmar que, de certa maneira, o próprio STF estava no banco dos réus ${ }^{37}$.

Compreender as pressões sobre o Supremo Tribunal Federal passa por observar a postura de editoriais e textos de opinião publicados em grandes jornais de circulação, que apontavam que os ministros também estariam sendo julgados no Mensalão. Diversos textos veiculados na imprensa escrita afirmavam que haveria prejuízos à imagem do Tribunal em caso de absolvição dos principais atores do processo, em especial, aqueles ligados ao Partido dos Trabalhadores ${ }^{38}$.

35 ARRUDA, Alexandre da Silva. O julgamento do caso Mensalão e a influência da mídia: um ponto fora da curva? Dissertação (Mestrado em Justiça Administrativa) - Universidade Federal Fluminense, Niteroi, 2014, p. 67.

36 HARTMANN, Ivar A. O julgamento e a opinião pública. In.: FALCÃO, Joaquim (Org.). Mensalão: diário de um julgamento. Supremo, mídia e opinião pública. 2. ed. rev., atual. e ampl. Rio de Janeiro: Forense; São Paulo: Método, 2015, p. 26-27.

37 ARRUDA, op. cit., p. 124.

38 BIROLI, Flávia; MANTOVANI, Denise. A parte que me cabe nesse julgamento: a Folha de S. Paulo na cobertura ao processo do "mensalão". Opinião 
É curioso observar que estas pressões também partiam de dentro do próprio STF, ressoavam na imprensa e retornavam como mais pressão por condenações. As manifestações de ministros à véspera de votos importantes, por entrevistas e artigos na imprensa, e as manifestações ao longo das sessões depreciando as motivações dos votos de seus colegas, reforçavam os papéis criados aos atores envolvidos e buscavam condicionar sua atuação ${ }^{39}$.

Nos últimos atos do Mensalão, entre os anos de 2013 e 2014, esta situação se tornou ainda mais explícita. Os novos ministros nomeados pela então Presidente Dilma Rousseff - Teori Zavaski e Luís Roberto Barroso foram retratados como indivíduos colocados na Corte para proteger os aliados do governo. O Ministro Gilmar Mendes falou à imprensa em um projeto de transformar o STF em uma "corte bolivariana" ${ }^{40}$, argumento que passou a ecoar com mais força, nos anos seguintes, por meio de movimentos que defendem o fechamento da Corte.

Outro ponto importante do julgamento consistiu na decisão em torno do cabimento ou não dos embargos infringentes, modalidade de recurso prevista no regimento do STF. Na narrativa de parte importante da imprensa, reconhecer o cabimento dos embargos significava garantir a impunidade dos acusados ${ }^{41}$, já que adiaria o trânsito em julgado da condenação.

Neste e em outros episódios, houve manifestações relevantes tanto na imprensa quanto nos embates entre ministros, no sentido de desqualificar os votos proferidos em favor dos acusados, apontados como manifestações "políticas" e "não técnicas".

O episódio mais marcante foi a discussão entre os Ministros Joaquim Barbosa e Luís Roberto Barroso sobre a dosimetria da pena, em que Barbosa admitia ter aumentado a pena apenas para evitar a prescrição, ao mesmo tempo em que classificava a manifestação de Barroso - pela redução das penas - como política. O Ministro Barroso, a esta época,

\footnotetext{
Pública, v. 20, n. 2, p. 204-218, ago. 2014, p. 212-213.

39 ARRUDA, op. cit., p. 96.

40 Ibidem, p. 101.

41 Ibidem, p. 98.
} 
afirmava que não tomava decisões com base nos jornais, que não se preocupava com a repercussão de suas decisões ${ }^{42}$.

As pressões internas, fizeram também do Mensalão um marco importante para redefinição de concepções teóricas apresentadas pelo Supremo Tribunal Federal. Dois exemplos muito importantes são a adoção deturpada da teoria do domínio do fato ${ }^{43}$ - utilizada para realizar uma espécie de responsabilidade penal pela posição ocupada - e o alargamento do alcance do tipo penal de corrupção passiva ${ }^{44}$ - tornando mais flexível a exigência da prática de ato de ofício como contrapartida pelo recebimento de vantagem indevida.

Na hipótese de Singer, o Mensalão é um dos elementos centrais para a ocorrência de um realinhamento das bases eleitorais no cenário nacional. O PT perdeu boa parte do apoio da classe média, que havia composto o eleitorado da primeira vitória presidencial do partido, em $2002^{45}$. Mesmo assim, o lulismo foi capaz de articular forças, com grande base de apoio popular, resultando na reeleição de Lula, em 2006, e mais duas eleições de Dilma Rousseff, em 2010 e 2014. No entanto, é preciso não simplificar as relações entre estes grandes processos de criminalização e possíveis interferências no processo eleitoral, pois esta análise exige maior cuidado e consideração de outros fatores, que não compõem o objeto do presente artigo ${ }^{46}$.

42 Ibidem, p. 96.

43 LEITE, Alaor. Domínio do fato, domínio da organização e responsabilidade penal por fatos de terceiros. Os conceitos de autor e partícipe na AP 470 do Supremo Tribunal Federal. In: GRECO, Luís; LEITE, Alaor; TEIXEIRA, Adriano; ASSIS, Augusto. Autoria como domínio do fato. Estudos introdutórios sobre o concurso de pessoas no direito penal brasileiro. São Paulo: Marcial Pons, 2014, p. 123-168.

44 QUANDT, Gustavo de Oliveira. Algumas considerações sobre os crimes de corrupção ativa e passiva. A propósito do julgamento do "Mensalão" (APn 470/MG do STF). Revista Brasileira de Ciências Criminais, São Paulo, v. 106, p. 181-214, jan./mar. 2014.

45 SINGER, André. Os sentidos do lulismo: reforma gradual e pacto conservador. São Paulo: Companhia das Letras, 2012, p. 53.

46 Como exemplo das complexidades dos reflexos eleitorais das operações anticorrupção: TELLES, Helcimara. Corrupção, legitimidade democrática e protestos: o boom da direita na política nacional? In: SOLANO, Esther; ROCHA, 
Iniciada no ano de 2014, a Operação Lava Jato tornou-se o símbolo dos movimentos de combate à corrupção, alçando os membros da chamada Força Tarefa (membros da Polícia Federal e do Ministério Público Federal) e o então juiz Sérgio Moro à condição de atores centrais na vida política brasileira. A Operação, que teve início no mesmo mês dos julgamentos dos embargos infringentes do Mensalão ${ }^{47}$, tem sido tratada como detentora de "personalidade própria" na esfera pública, passando a ocupar posição de "instituição" com maior destaque no país, em matéria de justiça criminal.

As pressões que se exerciam de fora e de dentro do Supremo Tribunal Federal ganham outra proporção, já que não é mais o Supremo o foro do julgamento de grande parte dos casos da Operação, mas a instância que deve "chancelar ou não" as práticas adotadas nas investigações e processos da Lava Jato. Mesmo nos casos do exercício da competência penal originária, julgando figuras centrais da vida política brasileira, havia certa atmosfera de validar ou não as práticas realizadas pela Lava Jato no primeiro grau de jurisdição. Os atores do sistema de Justiça que protagonizam a condução deste novo escândalo passaram a exercer pressão de maneira peculiar sobre o Supremo Tribunal Federal.

Se o Supremo, sob certa perspectiva, deu uma resposta aos "clamores da sociedade" no Mensalão ${ }^{48}$, ao longo da Lava Jato, foi construída uma imagem da Suprema Corte como entrave às pretensões do consórcio de atores do sistema de justiça que estava à frente da Operaçã $0^{49}$. Pretendemos analisar se esta percepção, do STF como contraponto às aspirações da Operação, encontra reflexos mais concretos nos julgamentos da Corte.

Uma determinada imagem do Supremo enquanto tribunal garantista e independente das pressões populares e midiáticas foi

Camila (Org.). As direitas nas redes e nas ruas. São Paulo: Expressão Popular, 2019, p. 55-89.

47 JUSTI, Adriana. Lava Jato completa 6 anos com 293 prisões; 'Está longe de acabar', diz delegado. G1, Rio de Janeiro, mar. 2020.

48 SOUSA, José Augusto Garcia de. As vozes do Supremo e a sociedade. In.: FALCÃO, Joaquim (Org.). Mensalão: diário de um julgamento. Supremo, mídia e opinião pública. 2. ed. rev., atual. e ampl. Rio de Janeiro: Forense; São Paulo: Método, 2015, p. 25-26.

49 RECONDO; WEBER, op. cit., p. 20-22. 
profundamente alterada pelos processos de abertura mencionados. Divisões internas entre grupos de ministros, com diferentes concepções acerca dos limites dos processos penais e do respeito às garantias constitucionais, já eram notadas no Mensalão e permanecem, com reconfigurações, ao longo da Lava Jato.

O discurso do Ministro Barroso é representativo para compreender o comportamento da Corte ao longo deste período. Pouco tempo após se tornar ministro, em 2013, Barroso afirmava que "ser juiz significa imunizar-se contra o contágio das paixões" 50 , ao mencionar sua posição no Mensalão, especialmente no episódio já mencionado, em que abriu divergência sobre o cabimento dos embargos infringentes, quando se contrapôs à posição do Ministro Joaquim Barbosa.

Nos últimos anos, o Ministro Barroso vem defendendo um papel do STF em "empurrar a história”, inclusive por meio do combate à corrupção. Para tanto, o ministro vangloria a tomada de posição do STF no Mensalão, afirmando que a "cidadania" impulsionou as mudanças na Corte a partir deste caso. O Supremo teria "interpretado esse sentimento" vindo da sociedade civil ${ }^{51}$. O tom geral destas manifestações assenta sobre uma premissa frágil de tornar o direito penal mais rigoroso para os "do andar de cima”, a partir da ação de "juízes corajosos"

A adesão irrestrita do Ministro Barroso - e outros, como os Ministros Luiz Fux e Edson Fachin - aos objetivos mais diretos dos membros da Operação Lava Jato é evidente, com contornos que extrapolam meros alinhamentos ideológicos no espectro político. Estas relações podem ser reposicionadas a partir das comunicações e conexões estabelecidas com os membros da Operação, expostas pelas diversas mensagens divulgadas

50 Disponível em: <https://www.conjur.com.br/2013-nov-03/stf-imune-paixoes-opiniao-publica-ministro-barroso>. Acesso em 02 jun. 2020.

51 BARROSO, Luís Roberto. Empurrando a história: combate à corrupção, mudança de paradigmas e refundação do Brasil (prefácio). In: PINOTTI, Maria Cristina (Org.). Corrupção: Lava Jato e Mãos Limpas São Paulo: Portfolio-Penguin, 2019, p. 09-19.

52 FERNANDES, Daniel Fonseca. Você não ouviu o samba que eu lhe trouxe. Empório do Direito, Florianópolis, jun. 2018. Disponível em: <http://emporiododireito.com.br/leitura/voce-nao-ouviu-o-samba-que-eu-lhe-trouxe>. Acesso em 30 jun. 2018. 
na série de reportagens conhecida como Vaza Jato ${ }^{53}$. Os membros da Operação, muitas vezes buscaram pressionar, constranger e acuar ministros do STF com posições divergentes das suas.

Para além destas ligações diretas entre membros da Lava Jato e do Supremo Tribunal Federal, é possível perceber também que os vínculos da Operação com a imprensa ocuparam um papel central na narrativa hegemônica do lavajatismo, indutora de medidas concretas na política criminal, inclusive da jurisprudência da Suprema Corte.

As conexões complexas entre a grande imprensa e as agências judiciais é retratada por Feres Jr., Barbarela e Bachini como uma relação de "mutualismo", em que ambos se beneficiam, sem necessariamente desenvolver uma interdependência fisiológica. Para estes autores, a Lava Jato possibilita uma mudança de paradigma das práticas da imprensa sobre os escândalos políticos, em razão de certa suavização das ligações com os partidos tradicionais de centro-direita e uma aproximação intensa com instituições do sistema de justiça ${ }^{54}$.

A tendência geral desta ligação entre imprensa e agências judiciais, na Lava Jato, teve como efeito central a redução da política à moral, num processo frequente de deslegitimação das instituições políticas de representação direta pelo voto, com especial enfoque nas ações e investigações direcionadas contra o Partido dos Trabalhadores ${ }^{55}$.

Por outro lado, o discurso construído sobre as agências judiciais é marcado por sua caracterização enquanto instituições neutras, que realizam trabalho técnico. Há assim um sentido de "superioridade moral perante o mundo corrupto da política" ${ }^{56}$.

É preciso observar que os bônus políticos da Operação e de sua exposição midiática se dirigem à figura personalizada de determinados juízes, em especial Sergio Moro, e ao grupo de Procuradores

53 FILHO, João. Como Barroso, Fachin e Fux blindaram a Lava Jato no STF. The Intercept Brasil, out. 2019.

54 FERES JR., João; BARBARELA, Eduardo; BACHINI, Natasha. A Lava Jato e a mídia. In: KERCHE, Fábio; FERES JR., João (Coord.). Operação Lava Jato e a democracia brasileira. São Paulo: Contracorrente, 2018, p. 200.

55 Ibidem, p. 208-214.

56 Ibidem, p. 217. 
Federais a frente da Operação. O STF não colhe os frutos dessa imagem de órgão técnico e neutro. Antes o contrário, o Supremo é alvo frequente das pressões para que valide os atos praticados no contexto da Lava Jato.

O próprio Sergio Moro, curiosamente tomado como o maior símbolo da Operação, havia escrito, anos antes, ao avaliar a operação Mãos Limpas, na Itália, sobre a necessidade de manter o "interesse do público elevado" por meio do constante fluxo de revelações, que, se utilizando de prisões, confissões e publicidade gerariam um "círculo virtuoso" 57 . $\mathrm{Na} 13^{\mathrm{a}}$ Vara Federal de Curitiba, onde exerceu suas funções, havia uma assessora de imprensa, que fornecia à mídia narrativas sob a perspectiva das agências policiais e judiciais ${ }^{58}$.

Também são conhecidas as relações diretas dos membros da Operação com determinados jornalistas e órgãos de comunicação alinhados a seus interesses mais imediatos, que recebiam informações em primeira mão, ao passo em que retribuíam, por vezes, com informações sigilosas ${ }^{59}$. É possível afirmar que os grandes meios de comunicação e alguns sites de notícias se transformaram em verdadeiros "porta-vozes" da Operação Lava Jato $^{60}$. Os vazamentos seletivos de informações e a narrativa construída a partir delas são centrais na conformação das pressões.

Estas relações estabelecidas no contexto da Operação Lava Jato encontram uma hipótese explicativa nas práticas de lawfare, ou seja, no uso estratégico do direito com objetivo de deslegitimação de determinados inimigos. Uma das dimensões centrais, nesta prática, é o uso da imprensa para obter determinados efeitos, como a legitimação de operações direcionadas, viabilização de condenações sem provas suficientes, fomento à

57 MORO, Sergio Fernando. Considerações sobre a Operação Mani Pulite. Revista CEJ, n. 26, p. 56-62, jul./set. 2004.

58 AUDI, Amanda. Entrevista: “a imprensa 'comprava' tudo”. Assessora de Sergio Moro por seis anos fala sobre a Lava Jato. The Intercept Brasil, out. 2018.

59 BALTHAZAR, Ricardo. Mensagens vazadas da Lava Jato indicam favorecimento a jornalistas aliados. Folha de São Paulo, dez. 2019.

60 LEAL FILHO, Laurindo Lalo. O jogo combinado da Lava Jato com a mídia. In: RAMOS FILHO, Wilson; NASSIF, Maria Inês; MELO FILHO, Hugo Cavalcanti; GONÇALVES, Mírian. Relações obscenas: as revelações do The Intercept/ BR. São Paulo: Tirant lo Blanch, 2019, p. 31-33. 
exigência da condenação pela opinião pública e indução a uma percepção generalizada de culpa ${ }^{61}$.

Este conjunto de fatores compõem um arsenal de pressões bem dirigidas com o objetivo de pressionar as agências judiciais a "validar" as práticas da Lava Jato. Cria-se uma atmosfera, a partir destas ações, em que divergências em relação às medidas tomadas na Operação se tornam sinônimo de complacência com a corrupção e suspeição dos atores judiciais. A pressão destes movimentos chega ao Supremo Tribunal Federal, produzindo efeitos concretos.

As relações dos ministros com as "vozes das ruas" se apresenta de forma complexa no período pós-Mensalão. A voz das ruas - elemento histórico a autorizar práticas autoritárias no campo do direito penal ${ }^{62}-$ passa a se misturar, em grande medida, com as mensagens emitidas pela imprensa e movimentos sociais organizados, alimentados pelas agências judiciais e policiais da Operação. A voz que chega aos ouvidos do Supremo Tribunal Federal tem o timbre que vem dos gabinetes da Operação Lava Jato.

As conexões entre Procuradores da Lava Jato e movimentos da sociedade civil foram utilizadas, em diversos momentos, para fazer pressão nas decisões do STF, como na escolha do Relator da Lava Jato na Corte, após a morte de Teori Zavaski, orquestrando uma campanha contra nomes específicos, como os Ministros Gilmar Mendes, Ricardo Lewandowski e Dias Toffoli. Os procuradores da Lava Jato buscavam "um jeito elegante de pressionar", fazendo parecer que a origem de vários movimentos no campo da política criminal direcionados ao STF eram demandas espontâneas da sociedade civil, como forma de conferir maior legitimidade e não "melindrar o STF"

As pressões que partiam do grupo de Procuradores da Lava Jato não poupavam sequer a Procuradoria Geral da República, órgão máximo

61 ZANIN, Cristiano; MARTINS, Valeska; VALIM, Rafael. Lawfare: uma introdução. São Paulo: Editora Contracorrente, 2019, p. 51-72.

62 CASARA, Rubens. Estado pós-democrático: neo-obscurantismo e gestão dos indesejáveis. 3. ed. Rio de Janeiro: Civilização Brasileira, 2018, p. 171-178.

63 NEVES, Rafael; MARTINS, Rafael Moro. 'Vou te pedir pra ser laranja em outra coisa'. Deltan e Lava Jato usaram Vem Pra Rua e instituto Mude como lobistas para pressionar STF e governo. The Intercept Brasil, ago. 2019. 
do Ministério Público com atribuição para atuar nos casos de foro de privilegiado perante o STF. O relato do próprio Procurador Geral, Rodrigo Janot, registra as tentativas de interferência dos Procuradores da Operação no caso das denúncias contra o ex-Presidente Lula ${ }^{64}$.

Neste cenário, é preciso compreender que o Ministério Público (MP) se tornou protagonista no cenário institucional brasileiro. Para Kerche e Marona, o MP passou, desde a redemocratização, por um processo multifatorial de autonomização, que possibilitou a ocorrência de dois desdobramentos essenciais: (i) tendências monopolistas dentre as instituições penais (passando a abarcar procedimentos de investigação, com chancela do STF, e definição de penas, por meio da delação premiada); (ii) protagonismo político, apresentando-se como instituição neutra, com pretensão de "representação total do interesse da sociedade brasileira"65.

É esta estrutura que possibilitou ao Ministério Público articular relações próximas com a imprensa, determinar a pauta de movimentos sociais, negociar estratégias com o juiz da causa e pressionar o Supremo Tribunal Federal.

Deste modo, as agências judiciais que compõem a Lava Jato centralizam a pauta da política criminal, sob o signo do combate à corrupção, e se colocaram como atores essenciais do cenário político nacional.

Neste cenário, diversas decisões importantes foram tomadas pelo Supremo Tribunal Federal sob a explícita influência dos membros da Lava Jato, nos bastidores, nas redes e na imprensa. Um caso exemplar é a virada de entendimento da Corte a respeito do cumprimento de pena após condenação em segunda instância, em $2016^{66}$, que passou a ser tratada como pauta prioritária, essencial para o combate à corrupção.

64 JANOT, Rodrigo. Nada menos que tudo. São Paulo: Planeta Brasil, 2019, p. 172-173.

65 KERCHE, Fábio; MARONA, Marjorie. O Ministério Público na Operação Lava Jato: como eles chegaram até aqui? In: KERCHE, Fábio; FERES JR., João (Coord.). Operação Lava Jato e a democracia brasileira. São Paulo: Contracorrente, 2018, p. 69-100.

66 AMARAL, Augusto Jobim do; CALEFFI, Paulo Saint Pastous. Pré-ocupação de inocência e execução provisória da pena: uma análise crítica da modificação jurisprudencial do STF. Revista Brasileira de Direito Processual Penal, Porto Alegre, v. 3, n. 3, p. 1073-1114, set./dez. 2017; ESTELLITA, Heloisa. A flexibilização da legalidade no Supremo Tribunal Federal: o caso da execução 
É observando este cenário de reconfiguração do papel do STF, a partir das pressões de dentro e de fora da Corte, nos processos do Mensalão e da Lava Jato, que este artigo analisa as manifestações dos ministros sobre a corrupção, nas votações realizadas entre os anos de 2015 e 2017.

\section{Os discursos Sobre a corrupÇÃo no Supremo Tribunal FEDERAL (2015-2017)}

O acesso aos discursos dos ministros do Supremo Tribunal Federal sobre a corrupção foi realizado através da coleta de decisões judiciais. A análise qualitativa destes julgados tem como objetivo identificar os principais argumentos mobilizados pelos ministros, no contexto dos movimentos de reposicionamento do STF no cenário político brasileiro.

O universo de análise ${ }^{67}$ definido para esta pesquisa consiste na totalidade dos acórdãos (decisões colegiadas) do Supremo Tribunal Federal a respeito do crime de corrupção passiva, entre janeiro de 2015 e junho de 2019. Para acessar este conjunto de decisões, foi utilizado o mecanismo de pesquisa de jurisprudência do site do STF, em novembro de 2019, por meio da função de busca pelo dispositivo da legislação, selecionando o artigo 317 do Código Penal como filtro. Foram encontrados, entre janeiro de 2014 e junho de 2019, cento e vinte e dois acórdãos.

Em virtude do tamanho dos documentos e das possibilidades de realização desta pesquisa, foram selecionadas as decisões proferidas entre janeiro de 2015 e dezembro de 2017, compreendendo, deste modo, o ano seguinte ao fim do Mensalão e o início da Lava Jato, até o ano anterior as eleições presidenciais de 2018.

Deste universo, obteve-se a amostra operacional de 55 (cinquenta e cinco) acórdãos, que foram analisados ao longo desta pesquisa. Estes

da condenação sujeita a apelos extremos. Revista Brasileira de Direito Processual Penal, Porto Alegre, v. 4, n. 2, p. 709-730, mai./ago. 2018.

67 PIRES, Álvaro. Amostragem e pesquisa qualitativa: ensaio teórico e metodológico. In: POUPART, Jean; DESLAURIERS, Jean-Pierre; GROULX, Lionel -H.; LAPERRIÈRE, Anne; MAYER, Robert; PIRES, Álvaro. A pesquisa qualitativa: enfoques epistemológicos e metodológicos. 4. ed. Petrópolis: Vozes, 2014, p. 168. 
acórdãos foram predominantemente proferidos pelas Turmas do STF, havendo apenas cinco julgados pelo Plenário da Corte ${ }^{68}$.

Desta amostra, foram identificados em sete acórdãos discursos sobre a corrupção que extrapolavam a mera análise dogmática do tipo penal. A partir da análise documental, foram identificadas seis categorias a partir discursos apresentados: (a) elogio da Lava Jato e paralelo com o Mensalão; (b) criminalização de grupos políticos; (c) visões sobre a impunidade; (d) corrupção enquanto tragédia brasileira; (e) os limites do Estado de Direito; e (f) as reações do STF. Cada uma destas categorias será analisada de maneira separada, buscando facilitar a compreensão destas manifestações.

\subsection{Elogio da Lava Jato: paralelo com Mensalão e os objetivos da CORRUPÇÃO}

Uma das primeiras categorias que podemos destacar nos julgados da era "Pós-Mensalão" é o elogio inicial à Operação Lava Jato, sendo tratada pelos ministros como o maior fenômeno de corrupção já verificado no país. Esta perspectiva, que eleva a Lava Jato a uma condição superlativa, surge da comparação com o Mensalão, em que o Ministro Gilmar Mendes chega a afirmar, de forma irônica, que o Mensalão seria de competência do "juizado de pequenas causas".

De outro lado, também foram traçados paralelos entre os dois casos, afirmando a semelhança entre os eventos, pela perspectiva de que seria “difícil separar o 'Mensalão' do 'Petrolão”" (termo que se refere às investigações da Lava Jato), pois teriam um núcleo duro idêntico, nas palavras do Ministro Gilmar Mendes ${ }^{69}$.

68 Esta predominância ocorre em razão da mudança regimental que, logo após o Mensalão, em 03 de junho de 2014, alterou o art. 5, inciso I, do Regimento Interno do STF, estabelecendo as Turmas como local para julgamento das ações penais originárias contra Deputados Federais e Senadores, que representam a maior parte dos detentores do foro por prerrogativa de função perante aquele Tribunal.

69 HC 128.278/PR - STF - Segunda Turma - Rel. Teori Zavascki - julg.: 18.08.2015. 
O Ministro Celso de Mello, no mesmo contexto, afirmou que desde o Mensalão tem-se visto que a corrupção contaminou as instituições estatais e o aparelho do Estado como um todo, e que esse fato pode ser observado a partir dos diversos elementos de informações que teriam sido reunidos graças a Lava $\mathrm{Jato}^{70}$.

Apesar do discurso recorrente da similaridade do Mensalão e as condutas investigadas pela Lava Jato, a Suprema Corte também faz certas diferenciações e aponta peculiaridades em cada evento, que revelariam, por exemplo, que no Mensalão a corrupção teria se instalado para atingir fins políticos, enquanto os casos investigados pela Operação Lava Jato não teriam apenas propósitos essencialmente políticos, mas também de enriquecimento ilícito $^{71}$, pessoal, dando um tom de maior reprovabilidade desta conduta.

Em outros momentos, a Corte expressou um discurso que não diferencia a destinação das verbas oriundas da corrupção para campanhas políticas ou para enriquecimento pessoal, como nos votos do Ministro Luís Roberto Barroso ${ }^{7273}$.

Deste modo, os discursos dos ministros apresentam, em linhas gerais, uma visão positiva sobre a atuação da Corte no Mensalão e traçam um cenário de maior gravidade sobre os crimes imputados no contexto da Lava Jato. O que transparece dos discursos é a necessidade de, mais uma vez, agir com rigor diante dos casos de corrupção, seja ela destinada ao financiamento da atividade política ou enriquecimento particular.

\subsection{CRIMINALIZAÇÃo de GRUPO POLITICO E FISIOLOGISMO}

Outro discurso que se apresenta nos acórdãos analisados é de que a corrupção teria se impregnado no seio de determinadas agremiações partidárias, degradando a atividade política no país.

70 HC 137.728/PR - STF - Segunda Turma - Rel. Edson Fachin - Red. Acórdão: Dias Toffoli - julg.: 02.05.2017

71 HC 128.278/PR - STF - Segunda Turma - Rel. Teori Zavascki - julg.: 18.08.2015.

72 AC 4.327 AgR-terceiro/DF - STF - Primeira Turma - Rel. Marco Aurélio Red. Acórdão: Luís Roberto Barroso - julg.: 26.09.2017.

73 Inq 4.327 AgR-segundo/DF - STF - Tribunal Pleno - Rel. Edson. Fachin julg.: 19.12.2017. 
Na esteira dos paralelos traçados entre o Mensalão e a Lava Jato, nota-se um discurso de criminalização de determinados grupos políticos, principalmente o grupo que "estava no poder" quando foram deflagradas as investigações em questão. Por esta perspectiva, afirma-se que certos partidos políticos teriam se apropriado do Estado para extrair benesses, tanto para o próprio partido como para seus líderes e colaboradores, afirmando assim que o cenário de corrupção julgado pelo STF seria na verdade uma forma de governança. Apesar das ressalvas do Ministro Celso de Mello, que afirma não estar "incriminando a atividade política"74, as censuras direcionadas a determinados grupos políticos são evidentes.

Neste sentido, o maior enfoque das críticas no paralelo entre Mensalão e Lava Jato é o Partido dos Trabalhadores (PT), que ocupou a presidência de 2003 ao começo de 2016. Outros partidos, que compuseram a base dos governos petistas também são retratados de forma pejorativa, em menor grau, como o Partido Progressista (PP) e o Partido do Movimento Democrático Brasileiro (PMDB).

O maior destaque ao Partido dos Trabalhadores e seus líderes em especial os ex-Presidentes Lula e Dilma - também aparece na análise das manchetes dos principais jornais do país sobre a Lava Jato, entre 2014 e 2018, numa tentativa frequente de associá-los mais diretamente aos crimes imputados na Operação $0^{75}$.

Estas reflexões feitas nos julgamentos de processos da Lava Jato, eram reforçadas ao longo das votações, chegando a inferências que "dado partido político seria contra as privatizações das empresas estatais não por ideologia, mas por fisiologia", já que, de certa forma, haveria uma utilização privada das estatais, na medida que elas eram subordinadas aos interesses daquele grupo, conforme as palavras do Ministro Gilmar Mendes ${ }^{76}$.

Neste ponto, há um desdobramento essencial dos discursos que identificam a corrupção às atividades do Estado, apresentado como um entrave indevido à privatização. Por este discurso, busca-se, de forma

\footnotetext{
74 HC 137.728/PR - STF - Segunda Turma - Rel. Edson Fachin - Red. Acórdão: Dias Toffoli - julg.: 02.05.2017.

75 FERES JR.; BARBARELA; BACHINI, op. cit., p. 222-223.

76 HC 128.278/PR - STF - Segunda Turma - Rel. Teori Zavascki - julg.: 18.08.2015.
} 
direta, vincular a posição contrária à privatização à corrupção. Faz parecer que só o interesse em praticar atos de corrupção justifica a contrariedade aos processos de privatização. Criminaliza-se, deste modo, a divergência ideológica, a divergência de concepções sobre o Estado. Na outra face da moeda, reside a ideia do desenvolvimento da atividade privada como campo virtuoso, alheio a estes processos de apropriação indevida.

Os primeiros registros desses discursos em votações do STF ocorrem no segundo semestre de 2015 , momento em que a Operação Lava Jato estava em plena expansão, mas sem que houvesse condenações definitivas de pessoas pertencentes ao grupo político mencionado. Neste mesmo período, figuras importantes do Partido dos Trabalhadores (PT) foram presas, como o ex-Ministro José Dirceu. Pouco tempo depois, no primeiro semestre de 2016, o ex-Presidente Lula seria acusado e denunciado por ter enriquecido ilicitamente.

Apesar da criminalização de determinados grupos políticos e seus atores, que, por vezes, soava como uma culpabilização antecipada, em outros casos, que também tratavam de corrupção, há demonstração explícita de apreço pelos réus, que não são caracterizados como inimigos públicos. O voto do Ministro Luiz $\mathrm{Fux}^{77}$, em desfavor do ex-Senador e atual Deputado Aécio Neves, é o episódio mais agudo e representativo desta dinâmica.

O Ministro Fux registrou em seu voto escrito que nunca pensou em estar na posição de julgar "uma pessoa querida" que "sempre apreciou" e teve "inequívoco apoio popular, por meio de uma eleição expressiva para Presidente da República”. Afirmando que o Senador não teve o "gesto de grandeza" de se afastar do mandato, o STF iria "auxiliá-lo" para "poder comprovar, à sociedade, a sua ausência de toda e qualquer culpa nesse episódio, que acabou marcando, de maneira dramática, para nós que convivemos com ele, a sua carreira política”.

A manifestação pública e registrada de afeto, de sentimento de decepção e da intenção de "auxiliar" o réu a provar sua inocência destoa amplamente dos discursos apresentados sobre a corrupção, especialmente se analisado em comparação aos discursos dirigidos aos líderes petistas.

77 AC 4327 AgR-terceiro/DF - STF - Primeira Turma - Rel. Marco Aurélio - Red. acórdão Luís Roberto Barroso - julg.: 26.09.2017. 
Nestes discursos, é possível notar a presença de um julgamento rigoroso sobre determinado grupo político, acusado de "fisiologismo" ao ocupar o Estado para benefício próprio, ao passo em que outros réus contam com a compaixão e solidariedade de determinados ministros.

\subsection{VISÕES SOBRE A IMPUNIDADE: AUTOANÁLISE DO PAPEL DO STF NO COMBATE À CORRUPÇÃO}

O protagonismo judicial fez com que a Suprema Corte passasse a analisar (e reanalisar) sua postura perante à sociedade e às demais agências punitivas para que, aos olhos externos, o STF não fosse taxado como entrave ao combate à corrupção e à Operação Lava Jato.

É nesse contexto que surgem, em meio aos julgamentos, discursos preocupados em destacar que a função do Supremo Tribunal Federal em nada poderia ser comparada à desídia ou impenitência daqueles que ali estavam sendo julgados. Tal situação é impulsionada em razão da grande exposição midiática que se apresentava ao STF e consequentemente pelo receio da opinião pública e do jargão da impunidade.

Em algumas oportunidades, percebe-se o esforço por parte dos ministros em demonstrar que a imunidade parlamentar e a prerrogativa de foro de parte dos investigados e acusados, não significavam privilégios e nem que eventual demora de julgamento dos casos poderia ser razão para culpar a Corte pela impunidade no país ${ }^{78}$. O Ministro Dias Toffoli, em seu voto, se preocupou em fazer todo um apanhado histórico da legislação constitucional para apontar que após a Emenda constitucional $n^{\circ} 35 / 2001$ - que alterou a imunidade formal de deputados e senadores para que pudessem ser processados criminalmente sem a necessidade de licença prévia da respectiva Casa Legislativa. Além disso, o ministro observou que houve uma profusão de ações penais no âmbito da competência originária do Supremo Tribunal Federal, demonstrando em números a quantidade de processos sob a responsabilidade dos onze ministros.

Essa preocupação reside justamente pela cobrança das outras agências do sistema penal para que ocorra um resultado "efetivo" sobre

78 RHC 135.683/GO - STF - Segunda Turma - Rel. Dias Toffoli - julg.: 25.10.2016. 
as demandas que envolvessem casos de corrupção. O Ministro Gilmar Mendes, alertou sobre esse iminente constrangimento a que o Supremo é submetido pelas eventuais demoras nos julgamentos desses casos, citando especialmente as questões e demandas ligadas à Lava Jato ${ }^{79}$.

Não por outra razão, os Ministros Ricardo Lewandowski e Luís Roberto Barroso afirmaram que o Supremo Tribunal Federal tem aplicado a prerrogativa de foro da forma mais restritiva possível, visando evitar a inviabilidade das investigações e ações criminais em trâmite naquela instância ${ }^{80}$.

O Ministro Gilmar Mendes afirmou, como forma de demonstrar que julgamentos de ações penais com prerrogativa de foro no Supremo não eram sinônimo de negligência ou impunidade, que após acompanhamento de pesquisas à respeito do Mensalão, percebeu que à época em que o STF julgava o referido caso, outros processos que eram oriundos das mesmas investigações mas que, em razão do desmembramento, tramitavam em

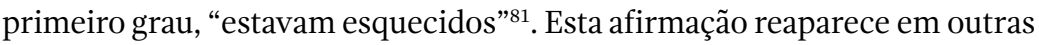
oportunidades, pelo mesmo Ministro Gilmar Mendes, explicitando que vários processos relativos ao Mensalão que estavam em primeiro grau de jurisdição ainda não teriam sido julgados. ${ }^{82}$

Esses discursos realizam a função de externar às agências da comunicação social e ao "grande público" o papel do STF, buscando afastar as ideias de que a Corte Suprema seria leniente com a corrupção e que a prerrogativa de foro significaria impunidade avalizada pelo Tribunal.

\subsection{CorrupÇÃo enquanto "tragédIa brasileIRA" E a REFundação do país}

A crise moral da sociedade brasileira também é pautada ao longo das votações dos casos de corrupção julgados no STF. Essa discussão,

79 RHC 135.683/GO - STF - Segunda Turma - Rel. Dias Toffoli - julg.: 25.10.2016.

80 Inq 4327 AgR-segundo/DF - STF - Tribunal Pleno - Rel. Edson. Fachin julg.: 19.12.2017.

81 RHC 135.683/GO - STF - Segunda Turma - Rel. Dias Toffoli - julg.: 25.10.2016.

82 HC 137.728/PR - STF - Segunda Turma - Rel. Edson Fachin - Red. Acórdão: Dias Toffoli - julg.: 02.05.2017 
em mais de um momento, surge ligada à ideia de tragédia. Uma tragédia brasileira causada pela corrupção.

O Ministro Luís Roberto Barroso é o ministro que mais representa e reproduz essa ideia nos votos. O discurso que expõe essa tragédia vem carregado com o pensamento da corrupção enquanto fruto sócio-histórico do Brasil, de "uma nação que se perdeu no caminho e naturalizou coisas erradas" 83 . Aqui percebe-se a relação da corrupção como "mito fundador" da nação, esta ideia recorrente no pensamento social brasileiro apropriada pelo discurso dos juristas para explicar o "estado das coisas". Muitas dessas "certezas" vêm das convicções do Ministro Barroso, por vezes, alinhadas com valores da "civilização europeia", em termos de abertura de certos princípios democráticos ${ }^{84}$.

A ideia do patrimonialismo tradicional brasileiro também aparece nos discursos do Ministro Barroso, ao afirmar que o "velho país", "a tradição" e o "velho modelo" são aqueles que eram coniventes com a corrupção e crimes de colarinho branco, gerando impunidade. Ao mesmo tempo, indica que essa história estaria mudando em razão do Mensalão e das operações policiais e judiciais que estavam em curso, citando especialmente a Lava jato, como se fossem a "mão da história", fazendo com que a corrupção começasse a ser efetivamente reprimida ${ }^{85}$.

$\mathrm{Na}$ toada dessa narrativa da "tragédia brasileira", ainda pode-se perceber expressões que surgem em outros votos do Ministro Barroso, para corroborar a ideia de combate à corrupção, descrevendo que o desvio de dinheiro público é "uma das maldições da República e que tem nos mantido atrasados e aquém do nosso destino" ${ }^{86}$. Tais expressões revelam que a agenda do combate à corrupção acaba por recriar um velho discurso e trazer o imaginário de "inimigo público". O Ministro Barroso define a punição desses crimes como medida capaz de conduzir a verdadeira refundação do país.

83 Inq 4327 AgR-segundo/DF - STF - Tribunal Pleno - Rel. Edson. Fachin julg.: 19.12.2017.

84 SOUZA, Jessé. A elite do atraso: da escravidão à Lava Jato. Rio de Janeiro: Leya, 2017, p. 186-187.

85 AC 4.327 AgR-quarto/DF - STF - Primeira Turma - Rel. Marco Aurélio Red. Acórdão: Luiz Fux - julg.: 20.06.2017.

86 AP 863/SP - STF - Primeira Turma - Rel. Edson Fachin - julg.: 23.05.2017. 
É importante notar que estes discursos foram proferidos em 2017, sempre nos votos do Ministro Luís Roberto Barroso. Em abril do mesmo ano, em uma comunicação destinada a uma universidade americana, o Ministro Barroso falou sobre a imagem do Brasil contemporâneo, baseando seu pensamento no patrimonialismo enquanto leitura social dominante dos brasileiros ${ }^{87}$.

Esse tipo de discurso faz do Poder Judiciário e, em especial do STF, um agente com a função de "empurrar a história”, na expressão já mencionada do Ministro Barroso. Os ministros, assim, representam figuras centrais da atividade política do país.

É importante observar que os ministros têm, em alguma medida, atuado em "blocos" dissonantes a respeito da Operação Lava Jato e suas práticas. Neste sentido, apesar desta seção contar apenas com manifestações do Ministro Barroso, é preciso observar que outros ministros e ministras não se manifestam com frequência de forma mais alongada, limitando-se a endossar as razões dos votos dos colegas.

Além dessa configuração de "blocos" a respeito de certos temas, outras questões são essenciais para as manifestações mais contidas ou para a ausência de manifestação, desde a personalidade mais ou menos reservada de cada um, até questões estruturais de gênero, que marcam sucessivas interrupções e deslegitimações das manifestações das ministras $^{88}$, configurando verdadeiro processo de silenciamento, ainda que seja para concordar.

\subsection{Os limites do Estado de Direito em Xeque}

O Supremo Tribunal Federal é o guardião da Constituição Federal e com isso tem o dever de zelar pelos direitos e garantias conferidos pelo Estado Democrático a todos os seus cidadãos. Em diversos julgamentos, os limites do Estado Democrático de Direito foram tensionados, inclusive pela pressão exercida por outras agências judiciais.

87 SOUZA, op. cit., p. 185-186.

88 GOMES, Juliana Cesário Alvim. O Supremo Tribunal Federal em perspectiva de gênero: mérito, acesso, representatividade e discurso. Direito \& Práxis, Rio de Janeiro, v. 7, n. 15, p. 672-673, 2016. 
Já no contexto da Lava Jato, diversos discursos apresentaram preocupações com os possíveis excessos que foram - e poderiam ser cometidos contra indivíduos, em razão da busca a qualquer custo do combate à corrupção. O Ministro Gilmar Mendes afirmou que, no Brasil, há uma cobrança para combater a corrupção com medidas cada vez mais duras, transpondo as linhas do Estado de Direito ${ }^{89}$. Na mesma oportunidade, destacou que não se podia esquecer da Constituição, das leis e garantias processuais.

Este fato é representativo das complexas relações e posicionamentos dos grupos de ministros sobre o combate à corrupção e seus limites. Trata-se de um discurso que recoloca em cena a necessidade de o Tribunal funcionar como contenção do poder de punir do Estado e proteção dos indivíduos.

Este tipo de manifestação tornou-se, ao longo do tempo, cada vez mais frequente por parte do Ministro Gilmar Mendes. Em outras ocasiões, ele afirmou que seria papel do STF, por vezes, agir de forma contramajoritária, se opondo aos desejos da maioria e contrariando a opinião pública - mesmo que vozes ecoassem pedindo aplicação de penas mais drásticas - para manter a estrutura do Estado de Direito, evitando punições arbitrárias. Neste sentido, o Ministro Gilmar Mendes também declarou que "a liberação de arbitrariedades contra determinadas pessoas hoje vai se convolar amanhã, na liberação de arbitrariedades, contra aquelas próprias pessoas que hoje aplaudiriam essas arbitrariedades" ${ }^{0}$ e a Corte Suprema não poderia ser condescendente com essa situação.

O Ministro Gilmar afirmou também que os casos de corrupção julgados pelo STF são temas sérios e que precisam ser analisados de acordo com a legalidade e dentro do Estado Democrático de Direito, para que se evite injustiças e erros evidentes. O processo criminal, neste sentido, não pode servir de instrumento de desforra ou vingança, e tudo que estiver fora da legalidade está fora dos padrões do Estado de Direito ${ }^{91}$.

89 RHC 135.683/GO - STF - Segunda Turma - Rel. Dias Toffoli - julg.: 25.10.2016.

90 HC 137.728/PR - STF - Segunda Turma - Rel. Edson Fachin - Red. Acórdão: Dias Toffoli - julg.: 02.05.2017

91 Inq 4.327 AgR-segundo/DF - STF - Tribunal Pleno - Rel. Edson. Fachin julg.: 19.12.2017. 


\subsection{As PRESSÕES DA LAVA JATO E AS REAÇÕES DO STF}

O Ministro Gilmar Mendes chamou atenção para os excessos de prisões cautelares utilizadas no desenvolvimento do "Petrolão" (identificado com a Lava Jato), destacando que o clamor público não pode dizer quando a prisão deve ser imposta e que a Corte não pode ceder a estas pressões, reafirmando a necessidade de analisar as questões de forma técnica e cuidadosa. Retomando o paralelo com o Mensalão, sobre a questão das prisões processuais, Gilmar Mendes destacou que a Suprema Corte julgou todo o processo do Mensalão sem decretar prisões preventivas, mesmo se tratando de caso relevante e de reiterada corrupção $0^{92}$.

Este discurso se apresenta como uma tentativa de recolocar limites nas ações tomadas nos processos da Lava Jato, afirmando que o STF não poderia ceder aos apelos puramente populares sobre o risco de semear um embrião autoritário no Estado Democrático de Direito ${ }^{93}$.

Outros discursos também surgem para explicitar e responder as pressões feitas pelos atores da Lava Jato. O Ministro Marco Aurélio, alertou que havia uma tendência em transformar a $13^{\text {a }}$ Vara Federal Criminal de Curitiba em um juízo universal ${ }^{94}$, devido a centralidade assumida pelos atores do sistema de justiça criminal daquele local - mesmo em situações e investigações que ocorriam em diversos estados e cidades do país, principalmente em Brasília/DF.

O Ministério Público também apareceu nos discursos do Ministro Gilmar Mendes que criticou as pressões e as precipitações do referido órgão acusador ao tratar de casos de corrupção. O alto número de Procedimentos de Investigação Criminal (PIC), abertos no âmbito do Ministério Público sem nenhum controle judicial das ações, foi objeto de crítica do ministro, ao passo em que destacou a baixa qualidade de muitas destas investigações ${ }^{95}$.

92 HC 137.728/PR - STF - Segunda Turma - Rel. Edson Fachin - Red. Acórdão: Dias Toffoli - julg.: 02.05.2017.

93 HC 137.728/PR - STF - Segunda Turma - Rel. Edson Fachin - Red. Acórdão: Dias Toffoli - julg.: 02.05.2017.

94 Inq 4327 AgR-segundo/DF - STF - Tribunal Pleno - Rel. Edson. Fachin - julg.: 19.12.2017.

95 Inq 4327 AgR-segundo/DF - STF - Tribunal Pleno - Rel. Edson. Fachin - julg.: 19.12.2017. 
Também é possível notar críticas contundentes às delações premiadas que passaram a ser elemento central no modus operandi da Lava Jato, com utilização desmedida das delações, sem a devida análise da causa e das provas. A situação estaria permeada pelo entusiasmo causado em razão da agenda do combate à corrupção, o que gerou juízos precipitados, carentes de provas que dessem sustentação ${ }^{96}$.

Para dar ênfase aos enormes equívocos que podem ser criados a partir da ânsia em alcançar resultados no combate à corrupção, o Ministro Gilmar Mendes citou um exemplo em que a delação de determinada pessoa teria ensejado o pedido de prisão de Senadores da República, notadamente um ex-Presidente e até então o presidente do Congresso Nacional. O pedido teria sido indeferido pelo Ministro Relator, Edson Fachin, e, após apurar os fatos mais detalhadamente, a própria Polícia Federal teria solicitado o arquivamento do inquérito, aberto em razão da delação que se demonstrara falsa ${ }^{97}$.

Assim, percebe-se nesses discursos, especialmente proferidos no ano de 2017, a tentativa de contrapor certas pressões entabuladas pelas agendas das agências judiciais no combate à corrupção.

Esta reação por parte dos ministros, em especial do Ministro Gilmar Mendes, explicitava os acirramentos internos na Corte, ao passo em que indicava um movimento de crítica aberta e contraposição às demandas institucionais da Operação Lava Jato.

É sintomático o julgamento da prisão após condenação em segunda instância, considerado essencial pelos membros do MPF. O Ministro Gilmar Mendes havia votado de maneira favorável, modificando seu posicionamento tradicional, permitindo a execução antecipada da pena, em $2016^{98}$. No entanto, a partir do ano seguinte, passou a tecer críticas aos

\footnotetext{
96 Inq 4327 AgR-segundo/DF - STF - Tribunal Pleno - Rel. Edson. Fachin julg.: 19.12.2017.

97 Inq 4327 AgR-segundo/DF - STF - Tribunal Pleno - Rel. Edson. Fachin - julg.: 19.12.2017.

98 FERNANDES, Daniel Fonseca; SANTANA, Tainan Bulhões. A presunção de inocência e a execução antecipada da pena no Supremo Tribunal Federal. In: CALDAS, Diana Furtado; ANDRADE, Gabriela Lima; RIOS, Lucas P. Carapiá. Arquivos da resistência: ensaios e anais do VII Seminário Nacional do IBADPP. Rio de Janeiro: Tirant lo Blanch, 2019, p. 303-304.
} 
efeitos daquela decisão do Plenário e concedeu determinadas liminares para impedir a execução antecipada, indicando que mudaria de posição, restabelecendo seu entendimento anterior.

\section{Considerações finaIS}

O Supremo Tribunal Federal, nas últimas décadas, passou por um processo intenso de ressignificação de seu papel. A abertura a um controle mais amplo por parte da sociedade e da imprensa e a ampliação de sua competência criminal são etapas importantes deste processo. É neste cenário que os discursos e projetos contra a corrupção têm exercido uma influência decisiva na construção dos discursos e tomadas de decisão da Corte.

Noções tradicionais no pensamento social brasileiro, como a de "patrimonialismo", têm sido mobilizadas em compreensões contemporâneas sobre a corrupção, destacando uma certa visão sobre Estado, como fonte da corrupção em contraposição a percepções do mercado como espaço da virtude e desenvolvimento. É possível perceber a presença destes discursos mesmo após a punição de uma parte relevante da burguesia brasileira, do setor da construção civil.

Neste contexto, os casos do Mensalão e da Lava Jato se apresentam como fenômenos de grande relevância para a compreensão dos papeis do STF e os discursos sobre a corrupção.

Se o Mensalão (2005-2014) foi importante para consolidar a exposição do STF ao olhar do público e às pressões frequentes da imprensa, sendo conduzido a ouvir "a voz das ruas", a partir da Lava Jato o Tribunal é tratado, frequentemente, como instância de chancela ou não dos atos da Operação. O STF é visto, em muitos momentos, como ameaça à Operação e passa a ser o destinatário de pressões bem calculadas das agências judiciais, especialmente do Ministério Público Federal, em articulação com a grande imprensa, movimentos sociais e com a instância de primeiro grau.

Esta conjuntura alçou o combate à corrupção à condição de fato central da vida política brasileira, levando o STF a construir respostas a estas demandas e reforçando fissuras na Corte e alinhamentos de grupos de ministros contrários ou favoráveis à Operação. 
Neste sentido, é possível identificar processos relacionados a decisões importantes no STF que provocaram a redução de garantias constitucionais e direitos fundamentais, como a execução da pena a partir da condenação em segundo grau, em 2016. É a partir deste cenário que foi possível enfrentar o problema desta pesquisa, que buscou compreender os discursos do STF sobre a corrupção.

Nos discursos dos ministros é possível observar uma postura de elogio e valorização do próprio STF no combate a corrupção, exaltando a atuação da corte no Mensalão, restrição ao foro e realização de julgamentos em tempo hábil. Deste modo, os ministros buscam afastar a ideia de que o STF dificulta o combate à corrupção.

Por outro lado, é possível perceber nas posturas de alguns ministros mudanças de comportamento importantes ao longo do tempo, passando do elogio do Mensalão e da Lava Jato, à crítica das ilegalidades e excessos cometidos pelas agências judiciais no contexto da Operação. O caso mais emblemático é do Ministro Gilmar Mendes, especialmente no ano de 2017, que passa a traçar críticas contundentes à extrapolação dos limites do Estado de Direito, ao uso excessivo de prisões processuais e à delação premiada.

É também possível perceber nos discursos dos ministros uma aplicação diferencial da ideia de rigidez necessária ao combate à corrupção, sendo notável as imagens construídas de um grupo que teria se apropriado do Estado para benefícios próprios - vinculada ao Partido dos Trabalhadores e outros que compuseram sua base de apoio - e o lamento e postura compreensiva com alguns acusados ligados a partidos de centro-direita, como o ex-Senador Aécio Neves. A distinção de tratamento é marcante, sem qualquer fundamento na gravidade das condutas ou consistência nas provas apresentadas.

Por fim, é possível constatar que o Supremo Tribunal Federal, entre os anos de 2015 e 2017, foi objeto frequente de pressões dirigidas pelas agências judiciais ligadas à Lava Jato, pela imprensa e movimentos sociais. Estas pressões reconfiguram o cenário traçado no Mensalão, colocando em xeque, com muito mais força, a legitimidade da Corte e de seus ministros.

A compreensão das oscilações dos entendimentos prevalecentes nas Turmas e no Plenário do STF exigem um acompanhamento 
aprofundado, observando suas influências nos processos eleitorais, as relações estabelecidas com a política e a força perante a opinião pública de movimentos externos à Corte, como a Lava Jato.

\section{REFERÊNCIAS}

ADORNO, Sérgio. Os aprendizes do poder: o bacharelismo liberal na política brasileira. 2. ed. São Paulo: Edusp, 2019.

AMARAL, Augusto Jobim do; CALEFFI, Paulo Saint Pastous. Pré-ocupação de inocência e execução provisória da pena: uma análise crítica da modificação jurisprudencial do STF. Revista Brasileira de Direito Processual Penal, Porto Alegre, v. 3, n. 3, p. 1073-1114, set./dez. 2017. https://doi.org/10.22197/rbdpp.v3i3.102

ARRUDA, Alexandre da Silva. O julgamento do caso Mensalão e a influência da mídia: um ponto fora da curva? Dissertação (Mestrado em Justiça Administrativa) - Universidade Federal Fluminense, Niteroi, 2014.

AUDI, Amanda. Entrevista: "a imprensa 'comprava' tudo". Assessora de Sergio Moro por seis anos fala sobre a Lava Jato. The Intercept Brasil, out. 2018. Disponível em: <https://theintercept.com/2018/10/29/lava-jato-imprensa-entrevista-assessora/>. Acesso em: 19 jun. 2020.

AVRITZER, Leonardo. Operação Lava Jato, Judiciário e degradação institucional. In: KERCHE, Fábio; FERES JR., João (Coord.). Operação Lava Jato e a democracia brasileira. São Paulo: Contracorrente, 2018, p. 37-52.

BALTHAZAR, Ricardo. Mensagens vazadas da Lava Jato indicam favorecimento a jornalistas aliados. Folha de São Paulo, dez. 2019. Disponível em: <https://www1. folha.uol.com.br/ilustrissima/2019/12/mensagens-vazadas-da-lava-jato-indicamfavorecimento-a-jornalistas-aliados.shtml >. Acesso em: 19 jun. 2020.

BARATTA, Alessandro. Criminologia crítica e crítica do direito penal. 3. ed. Rio de Janeiro: Revan: Instituto Carioca de Criminologia, 2002.

BARROSO, Luís Roberto. Empurrando a história: combate à corrupção, mudança de paradigmas e refundação do Brasil (prefácio). In: PINOTTI, Maria Cristina (Org.). Corrupção: Lava Jato e Mãos Limpas São Paulo: Portfolio-Penguin, 2019, p. 09-19.

BATISTA, Nilo. Pena pública e escravismo. In: NEDER, Gizlene (Org.). História \& Direito: jogos de encontros e transdisciplinaridade. Rio de Janeiro: Revan, 2007, p. 27-62. 
BIROLI, Flávia; MANTOVANI, Denise. A parte que me cabe nesse julgamento: a Folha de S. Paulo na cobertura ao processo do "mensalão". Opinião Pública, v. 20, n. 2, p. 204-218, ago. 2014. https://doi.org/10.1590/1807-01912014202204

BOITO JR., Armando. Lava Jato, classe média e burocracia de Estado. In: BOITO JR., Armando. Reforma e crise política no Brasil: os conflitos de classe nos governos do PT. Campinas: Editora da Unicamp, 2018, p. 253-264.

CASARA, Rubens. Estado pós-democrático: neo-obscurantismo e gestão dos indesejáveis. 3. ed. Rio de Janeiro: Civilização Brasileira, 2018.

CHALOUB, Jorge; LIMA, Pedro Luiz. Os juristas políticos e suas convicções: para uma anatomia do golpe de 2016 no Brasil. Revista de Ciências Sociais, Fortaleza, v. 49, n. 1, p. 202-252, mar./jun. 2018.

DAMATTA, Roberto. O que faz o brasil, Brasil? Rio de Janeiro: Rocco, 1984.

ESTELLITA, Heloisa. A flexibilização da legalidade no Supremo Tribunal Federal: o caso da execução da condenação sujeita a apelos extremos. Revista Brasileira de Direito Processual Penal, Porto Alegre, v. 4, n. 2, p. 709-730, mai./ago. 2018. https://doi.org/10.22197/rbdpp.v4i2.141

FALCÃO, Joaquim. Direito, mídia e opinião pública. In.: FALCÃO, Joaquim (Org.). Mensalão: diário de um julgamento. Supremo, mídia e opinião pública. 2. ed. rev., atual. e ampl. Rio de Janeiro: Forense; São Paulo: Método, 2015, XXI-XXVII.

FAORO, Raymundo. Os donos do poder: formação do patronato político brasileiro. 5. ed. São Paulo: Globo, 2012.

FARIA, José Eduardo. Corrupção, justiça e moralidade pública. São Paulo: Perspectiva, 2019.

FERES JR., João; BARBARELA, Eduardo; BACHINI, Natasha. A Lava Jato e a mídia. In: KERCHE, Fábio; FERES JR., João (Coord.). Operação Lava Jato e a democracia brasileira. São Paulo: Contracorrente, 2018, p. 199-228.

FERNANDES, Daniel Fonseca. Você não ouviu o samba que eu lhe trouxe. Empório do Direito, Florianópolis, jun. 2018. Disponível em: <http://emporiododireito.com. br/leitura/voce-nao-ouviu-o-samba-que-eu-lhe-trouxe>. Acesso em 30 jun. 2018.

FERNANDES, Daniel Fonseca; SANTANA, Tainan Bulhões. A presunção de inocência e a execução antecipada da pena no Supremo Tribunal Federal. In: CALDAS, Diana Furtado; ANDRADE, Gabriela Lima; RIOS, Lucas P. Carapiá. Arquivos da resistência: ensaios e anais do VII Seminário Nacional do IBADPP. Rio de Janeiro: Tirant lo Blanch, 2019, p. 299-310. 
FILHO, João. Como Barroso, Fachin e Fux blindaram a Lava Jato no STF. The Intercept Brasil, out, 2019. Disponível em: < https://theintercept.com/2019/10/06/ barroso-fachin-fux-blindaram-lava-jato-no-stf/>. Acesso em 06 mai. 2020.

FONTAINHA, Fernando; LIMA, Amanda Evelyn. Judiciário e crise política no Brasil hoje: do Mensalão à Lava Jato. In: KERCHE, Fábio; FERES JR., João (Coord.). Operação Lava Jato e a democracia brasileira. São Paulo: Contracorrente, 2018, p. 53-68.

FREYRE, Gilberto. Casa-Grande \& Senzala. In: Obra escolhida. Rio de Janeiro: Editora Nova Aguillar, 1977.

GOMES, Juliana Cesário Alvim. O Supremo Tribunal Federal em perspectiva de gênero: mérito, acesso, representatividade e discurso. Direito \& Práxis, Rio de Janeiro, v. 7, n. 15, p. 652-676, 2016. https://doi.org/10.12957/dep.2016.25237

GOMES, Luiz Flávio. O jogo sujo da corrupção. Bauru: Astral Cultural, 2017.

GRECO, Luís; TEIXEIRA, Adriano. Aproximação a uma teoria da corrupção. In: LEITE, Alaor; TEIXEIRA, Adriano (Org.). Crime e política. Corrupção, financiamento irregular de partidos políticos, caixa dois eleitoral e enriquecimento ilícito. Rio de Janeiro: FGV Editora, 2017, p. 19-51.

HARTMANN, Ivar A. O julgamento e a opinião pública. In.: FALCÃO, Joaquim (Org.). Mensalão: diário de um julgamento. Supremo, mídia e opinião pública. 2. ed. rev., atual. e ampl. Rio de Janeiro: Forense; São Paulo: Método, 2015, p. 26-27.

HOLANDA, Sérgio Buarque de. Raízes do Brasil. 26. ed. São Paulo: Companhia das Letras, 1995.

JANOT, Rodrigo. Nada menos que tudo. São Paulo: Planeta Brasil, 2019.

JUSTI, Adriana. Lava Jato completa 6 anos com 293 prisões; 'Está longe de acabar', diz delegado. G1, rio de Janeiro, mar. 2020. Disponível em: <https://g1.globo.com/ $\mathrm{pr} /$ parana/noticia/2020/03/10/lava-jato-completa-6-anos-com-293-prisoes-esta-longe-de-acabar-diz-delegado.ghtml>. Acesso em: 10 mar. 2020.

KERCHE, Fábio; MARONA, Marjorie. O Ministério Público na Operação Lava Jato: como eles chegaram até aqui? In: KERCHE, Fábio; FERES JR., João (Coord.). Operação Lava Jato e a democracia brasileira. São Paulo: Contracorrente, 2018, p. 69-100.

KIRCHHEIMER, Otto. Criminal Law in National Socialist Germany. In: SCHEUERMAN. William. (Ed.) The Rule of Law Under Siege: selected essays of Franz L. Neumann and Otto Kirchheimer. Los Angeles: University of California Press, 1996, p. 172-194. 
LARA, Silvia Hunold. Campos da violência: escravos e senhores na Capitania do Rio de Janeiro, 1750-1808. Rio de Janeiro: Paz e Terra, 1988.

LEAL FILHO, Laurindo Lalo. O jogo combinado da Lava Jato com a mídia. In: RAMOS FILHO, Wilson; NASSIF, Maria Inês; MELO FILHO, Hugo Cavalcanti; GONÇALVES, Mírian. Relações obscenas: as revelações do The Intercept/BR. São Paulo: Tirant lo Blanch, 2019, p. 31-33.

LEITE, Alaor. Domínio do fato, domínio da organização e responsabilidade penal por fatos de terceiros. Os conceitos de autor e partícipe na AP 470 do Supremo Tribunal Federal. In: GRECO, Luís; LEITE, Alaor; TEIXEIRA, Adriano; ASSIS, Augusto. Autoria como domínio do fato. Estudos introdutórios sobre o concurso de pessoas no direito penal brasileiro. São Paulo: Marcial Pons, 2014, p. 123-168.

MARANI, Sílvio César Zákhia; BRITO, Mozar José de; SOUZA, Gustavo Costa de; BRITO, Valéria da Glória Pereira. Os sentidos da pesquisa sobre corrupção, Revista de Administração Pública, v. 52, n. 4, p. 712-730, jul./ago. 2018. https:// doi.org/10.1590/0034-7612175197

MIGUEL, Luis Felipe; COUTINHO, Aline. A crise e suas fronteiras: oito meses de “mensalão" nos editoriais dos jornais. Opinião pública, Campinas, v. 13, n. 1. jun. 2007, p. 97-123. https://doi.org/10.1590/s0104-62762007000100004

MORO, Sergio Fernando. Considerações sobre a Operação Mani Pulite. Revista CEJ, n. 26, p. 56-62, jul./set. 2004.

MOURA, Denise. Jogo de acusações: denúncias de mau governo e competição de interesses na América portuguesa. In: BIASON, Rita; LIVIANUI, Roberto (Org.). A corrupção na história do Brasil. São Paulo: Editora Mackenzie, 2019, p. 40-54.

NEVES, Rafael; MARTINS, Rafael Moro. 'Vou te pedir pra ser laranja em outra coisa'. Deltan e Lava Jato usaram Vem Pra Rua e instituto Mude como lobistas para pressionar STF e governo. The Intercept Brasil, ago. 2019. Disponível em: < https://theintercept.com/2019/08/11/deltan-lava-jato-vemprarua-lobby-stf/>. Acesso em: 11 jul. 2019.

PIRES, Álvaro. Amostragem e pesquisa qualitativa: ensaio teórico e metodológico. In: POUPART, Jean; DESLAURIERS, Jean-Pierre; GROULX, Lionel-H.; LAPERRIÈRE, Anne; MAYER, Robert; PIRES, Álvaro. A pesquisa qualitativa: enfoques epistemológicos e metodológicos. 4. ed. Petrópolis: Vozes, 2014, p. 154-211.

QUANDT, Gustavo de Oliveira. Algumas considerações sobre os crimes de corrupção ativa e passiva. A propósito do julgamento do "Mensalão" (APn 470/MG 
do STF). Revista Brasileira de Ciências Criminais, São Paulo, v. 106, p. 181-214, jan./mar. 2014.

RECONDO, Felipe; WEBER, Luiz, Os Onze: o STF, seus bastidores e suas crises. São Paulo: Companhia das Letras, 2019.

ROMEIRO, Adriana. A corrupção na Época Moderna - conceitos e desafios metodológicos. Revista Tempo, v. 21, n. 38, p. 216-237, dez. 2015. https://doi. org/10.20509/tem-1980-542x2015v213812

SCHWARCZ, Lilia Moritz. Sobre o autoritarismo brasileiro. São Paulo: Companhia das Letras, 2019.

SINGER, André. Os sentidos do lulismo: reforma gradual e pacto conservador. São Paulo: Companhia das Letras, 2012.

SOUSA, José Augusto Garcia de. As vozes do Supremo e a sociedade. In.: FALCÃO, Joaquim (Org.). Mensalão: diário de um julgamento. Supremo, mídia e opinião pública. 2. ed. rev., atual. e ampl. Rio de Janeiro: Forense; São Paulo: Método, 2015, p. 25-26.

SOUZA, Jessé. O patrimonialismo é o problema brasileiro? Revista Simetria, São Paulo, v. 1, n. 3, p. 29-40, 2017. Disponível em: <https://escoladecontas.tcm. sp.gov.br/images/simetria/revista-3/jesse_souza.pdf>. Acesso em: 27 jun. 2020.

SOUZA, Jessé. A Elite do Atraso: da escravidão à Lava Jato. Rio de Janeiro: Leya, 2017.

SUTHERLAND, Edwin. Crime de colarinho branco. Rio de Janeiro: Revan, 2015.

TELLES, Helcimara. Corrupção, legitimidade democrática e protestos: o boom da direita na política nacional? In: SOLANO, Esther; ROCHA, Camila (Org.). As direitas nas redes e nas ruas. São Paulo: Expressão Popular, 2019, p. 55-89.

ZANIN, Cristiano; MARTINS, Valeska; VALIM, Rafael. Lawfare: uma introdução. São Paulo: Editora Contracorrente, 2019.

ZAFFARONI, Eugenio Raúl; BATISTA, Nilo; ALAGIA, Alejandro; SLOKAR, Alejandro. Direito Penal Brasileiro: primeiro volume. 4. ed. Rio de Janeiro: Revan, 2011. 


\section{Informações adicionais e declarações dos autores (integridade científica)}

Agradecimentos (acknowledgement): À professora Lícia Regina pela revisão cuidadosa do texto.

Declaração de conflito de interesses (conflict of interest declaration): os autores confirmam que não há conflitos de interesse na realização das pesquisas expostas e na redação deste artigo.

Declaração de autoria e especificação das contribuições (declaration of authorship): todas e somente as pessoas que atendem os requisitos de autoria deste artigo estão listadas como autores; todos os coautores se responsabilizam integralmente por este trabalho em sua totalidade.

- Daniel Fonseca Fernandes: projeto e esboço inicial (conceptualization), desenvolvimento da metodologia (methodology), coleta e análise de dados (data curation), levantamento bibliográfico (investigation), revisão bibliográfica (investigation), redação (writing - original draft), participação ativa nas discussões dos resultados (validation), revisão crítica com contribuições substanciais (writing review and editing), aprovação da versão final .

- Tainan Bulhões Santana: desenvolvimento da metodologia (methodology), coleta e análise de dados (data curation), levantamento bibliográfico (investigation), redação (writing original draft), participação ativa nas discussões dos resultados (validation), revisão crítica com contribuições substanciais (writing - review and editing), aprovação da versão final.

Declaração de ineditismo e originalidade (declaration of originality): os autores asseguram que o texto aqui publicado não foi divulgado anteriormente em outro meio e que futura republicação somente se realizará com a indicação expressa da referência desta publicação original; também atestam que não há plágio de terceiros ou autoplágio. 
Dados do processo editorial

(http://www.ibraspp.com.br/revista/index.php/RBDPP/about/editorialPolicies)

- Recebido em: 24/07/2020

- Controle preliminar e verificação de plágio: 27/07/2020

- Avaliação 1:08/08/2020

- Avaliação 2:08/08/2020

- Avaliação 3: 10/08/2020

- Decisão editorial preliminar: 23/08/2020

- Retorno rodada de correções: 04/09/2020

- Decisão editorial final: 08/09/2020

\section{Equipe editorial envolvida}

- Editor-chefe: 1 (VGV)

- Editor-associado: 1 (RO)

- Revisores: 3

\section{COMO CITAR ESTE ARTIGO:}

FERNANDES, Daniel F.; SANTANA, Tainan B. Discursos sobre a corrupção nas votações no Supremo Tribunal Federal (2015-2017). Revista Brasileira de Direito Processual Penal, Porto Alegre, vol. 6, n. 3, p. 1345-1387, set./dez. 2020. https://doi.org/10.22197/rbdpp.v6i3.432

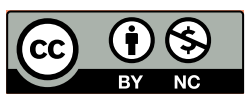

Esta obra está licenciada com uma Licença Creative Commons Atribuição-NãoComercial 4.0 Internacional. 